\title{
Meaning Components of Indonesian Concept of Taat 'Obedience' Lexeme
}

\author{
Sri Nardiati \\ \{Sri_nardiati@yahoo.co.id\} \\ Balai Bahasa Daerah Istimewa Yogyakarta
}

\begin{abstract}
This research examines the meaning of lexeme with the concept of taat 'obedient' in Indonesian. The approach used is intentional, with structural-semantic theory. The data collection used a different method of note-taking technique, tested by the contextual method. The analysis of meaning components in this study used the equivalent method with contrast and opposition procedures. There are 12 lexemes with the concept of taat 'obedient' in Indonesian. The meaning components are described based on three dimensions, namely the actor, receiver, and form. Based on the shared meaning components, the analyzed lexeme forms five branched and one unbranched structure with the taat 'obedient' lexeme as superordinate.
\end{abstract}

Keywords: lexeme, superordinate, meaning component, shared meaning component, diagnostic meaning component

\section{Introduction}

This research is entitled "Meaning Components of Indonesian Concept of" Taat 'Obedience' Lexeme". Komponen Makna lexeme yang Berkonsep 'Taat' dalam Bahasa Indonesia". This research is carried out on the consideration that the use of the word taat 'obedient' has a very high frequency, especially in the religious realm. According to the Big Indonesian Dictionary (online) the word taat 'obedient' means' to always submit (to God, government, etc.); obey '. The meaning of the word has a high enough power to personality formation, as a foundation in life to become a noble human being.

On social media, we often find the use of words that contain insults, for example on Facebook, Twitter, Instagram, etc. The use of these words is very unfavorable because it can hurt and even harm others [1]. For this reason, the topic of a lexeme that has positive meanings is examined, for example obedient, obedient, obedient, loyal, and the like.

The data of the study are categorized as a state-type event. Implicitly, the category has been mentioned in several previous research results, as follows.

1) According to [2] Martubongs (2015: 131--132), in the results of his research entitled "Peran Semantis Verba Bahasa Nafri", state verbs are part of process verb and action verb category. The state verb contains a cognition component, which corresponds to the verb percaya 'believe', merenung 'reflect'; knowledge component, which corresponds to the words tahu 'know', mengerti 'understand', menguasai 'master', and the component emosi 'emotion' which corresponds to the words kecewa 'disappointed', malu 'embarrassed', bingung 'confused' in Indonesian. 
2) According to [3] Sutarsih (2017) in his research entitled "Kata Bermakna Membesar dalam Bahasa Jawa", that studied the words mlenthing, njembluk, methunthung which are categorized as state activities, some words in a lexical field are connected by a component of diagnostic meaning or differentiation (Sutarsih, 2017: 193). The statement is a manifestation of her carelessness. Because she said that a set of lexemes is in a lexical field and it is not connected by a component of a diagnostic meaning or a component of differentiation. However, it is connected by a common component of meaning. The diagnostic component can be identified after all the meaning components in each lexeme have been described using the interlexeme contrast technique in a related lexical field.

3) According to [4] Sutarsih (2018) in her research entitled "Hiponimi Kata Mencuci dalam Bahasa Indonesia", metaphorical state verb data are used, for example, cuci mata eye washing and cuci otak brainwashing (Sutarsih, 1918: 99). Furthermore, the lexemes are grouped under the washing lexemes. The analysis technique is the component meaning analysis. The describing technique has not followed the convention practiced by semantic experts, especially to the writing of meaning components that should be distinguished, namely capital letters.

4) According to [5] Nurlina (2012) in her research entitled "Leksikon Bermakna 'Aktivitas Telinga' dalam Bahasa Jawa" budheg and krungu categorized as state activity are studied. The results show that there are two types of ear activity, namely accidental and deliberate. Accidental activities, for example, rungokake, simak, tilingake, meanwhile deliberate activities are rungu/krungu, rungoni, krungu-krungu (Nurlina, 2012: 32). This statement is reversed, the accidental activity in Javanese can be in the form of rungu/krungu, rungoni, and krungu-krungu lexeme, while those classified as deliberate activities in Javanese can take the form of rungokake, simak, and tilingake lexeme.

5) [6] Darmawati M.R (2014) in her research entitled "Medan Makna Rasa Mata dalam Bahasa Bugis Bone", there is an inaccurate use of the term. This can be seen in the result that there are 16 meaning fields for the sense of the eye (Darmawati, 2014: 61--70). After observing closely, the point is in the Bugis Bone language there are 16 lexemes. Among 16 lexemes there are static verbs, which correspond to the Indonesian vocabulary, for example, kabur blurred, berair watery, bernanah festering, mengantuk sleepy, memera squeezing, and berkunangkunang lightheaded.

6) [7] Khak (2013) in his research entitled "Verba Indrawi Penglihatan: Analisis Makna", the analyzed data is limited to nine lexemes of sensory activity: melihat 'seeing', melirik 'glancing', mengerling 'glancing', menjeling, memalis 'peering', menengok 'taking a look', melengos 'looking away', menoleh 'look toward', mengintip 'peeking'. The research states there are activity mengerling 'glancing' and menjeling 'peeking' indicating state activity. The nine lexemes are analyzed for their meaning components, common meaning components, and their differentiating meaning components. Descriptions have followed writing techniques commonly practiced by previous experts, for example, encapsulation in the writing of meaning components, italics in the analyzed lexemes, and marking of the semantic reactions possessed by each lexeme.

From the results of the semantic research, it can be seen that research with the lexeme object which means taat "obedient" in Indonesian has not been done. Therefore, this research focuses on this lexeme. The research aims to identify the set of lexemes included in the taat 'obedient' lexeme, its meaning components, its shared meaning components, its diagnostic meaning components, and its hierarchical structure.

The benefits of this research are practical and theoretical. Practically, the result can be used as material for consideration in developing vocabulary in the dictionary and perfecting the explanation of entries in the dictionary. The result of this study can also be used as material for 
the preparation of an Indonesian thesaurus and encyclopaedia. Theoretically, the results of this study can be used as material to complete the semantic linguistic theory of languages in the archipelago. The results can be used as an input in the implementation of semantic research for linguistic researchers in Indonesia. The theories and methods used in this study are presented in the following paragraph.

\section{Research Methods}

In this study, an intentional approach was used, the researcher's attention was focused on the conceptual structure of each lexeme object of the study [8]. The theory used is structural semantics as suggested by [8], that in a lexical field there is a set of lexemes in which there is an order of relations to form the unity of meaning. A set of meaning components in a set of lexemes of a lexical field is correlated horizontally and vertically based on contrast and comparison procedures [8]. Thus, the common component in a set of lexemes in a lexical field can be known [8].

The researcher's attention was focused on the meaning components of the data lexeme units. To facilitate the description of the meaning components in this set of lexemes, the concept of dimensions is used. This is in line with the opinion of Dupuy-Engelhardt (1990: 45 - 47) in [9] which states that when the lexeme unit has a complex and broad meaning component so that the meaning component is quite a finding, the analysis uses the concept of the dimension of meaning. The hierarchical structure of a set of lexemes on a lexical field can be known. The formed hierarchical structure is based on contrasting meaning in a set of lexemes [8] and [10]. Therefore, the lexeme status as superordinate (hyperonym) or subordinate (hyponym) can be identified.

The lexeme meaning relation which has the status as subordinate, and superordinate is classified as inclusion or coverage relation [8]. The meaning component of the subordinate lexeme is included in the meaning component of the superordinate lexeme. There is an impact of unidirectional involvement. In a sentence context, a subordinate (hyponym) lexeme can be replaced by a lexeme that has a superordinate (hyperonym) status. However, a superordinate (hyperonym) lexeme cannot be called a subordinate (hyponym) lexeme [10]. For example, hormat 'respect' is included in taat 'obedient', but taat 'obedience' is not always hormat 'respectful'. The reason is the meaning component of hormat 'respect' is included in taat 'obedience' lexeme.

The data collection in this study used a separate method, the determining tool is the language part that becomes the data. The technique is to see and then take notes. In the analysis, the equivalent method is used, the determining tool in the form of reality that is indicated or referred to by the language itself [11]. The collected data was tested using the contextual method [10] in the form of $\mathrm{X}$ design belonging to $\mathrm{Y}$. The lexical unit $\mathrm{X}$ is filled with lexeme which becomes hyponym, while $\mathrm{Y}$ is filled with lexeme which becomes superordinate or hyperonym.

In the meaning components analysis of the study, the marking technique was used in each semantic reaction contained in each lexeme. Techniques commonly used by semantic researchers, one of them, can be seen in the results of research conducted by [12] Nardiati (2016) and [13]. The + (plus) sign indicates the presence of a meaning component. The - (minus) sign indicates the absence of a meaning component. The 0 (zero) sign indicates the neutrality of the meaning component in a particular lexeme. The lexeme that becomes the data is italicized. The 
meaning component is written in capital letters. Writing definitions are enclosed in single quotation marks. The source of data in this study is the Big Indonesian Dictionary (online).

\section{Results and Discussion}

The results showed that the lexeme with the concept of taat 'obedient' in Indonesian was twelve words, as follows.
1) bakti 'devotion'
3) menurut 'obey'
5) saleh 'pious'
2) hormat 'respect'
7) sembah 'worship'
4) patuh 'subservient'
6) setia 'loyal'
9) taat 'obedient'
8) sopan 'polite'
11) takluk 'surrender'
10) takwa 'piety'
12) tunduk 'submission'

The meaning components contained in these lexemes can be described based on three dimensions, namely 'DOER', 'RECIPIENT', and 'FORM'. Based on these three dimensions, the meaning components of a set of lexemes as data can be entered into the following matrix.

Table 1. The Matrix of Meaning Component A Set of Indonesia Taat 'Obedient' Concept Lexemes

\begin{tabular}{|c|c|c|c|c|c|c|c|c|c|c|c|c|c|c|c|}
\hline \multirow{2}{*}{$\begin{array}{l}\mathrm{N} \\
\mathrm{O}\end{array}$} & Dimension & DOER & \multicolumn{8}{|c|}{ RECIPIENT } & \multicolumn{5}{|c|}{ FORM } \\
\hline & $\begin{array}{l}\text { Component } \\
\text { Lexeme }\end{array}$ & 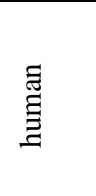 & 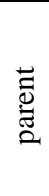 & 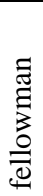 & 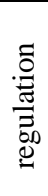 & ت & 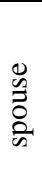 & $\stackrel{b 0}{.}$ & $\begin{array}{l}\overrightarrow{0} \\
\stackrel{0}{0}\end{array}$ & 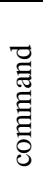 & 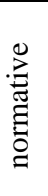 & 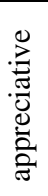 & $\begin{array}{l}\text { : } \\
\text { क्ञ } \\
\vdots \\
\vdots\end{array}$ & 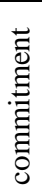 & 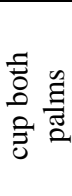 \\
\hline 1 & bakti & $V_{t}$ & + & 0 & - & + & - & + & - & - & + & + & 0 & 0 & - \\
\hline 2 & hormat & + & + & + & - & - & + & + & - & - & + & + & 0 & 0 & - \\
\hline 3 & menurut & + & + & + & + & + & 0 & + & -- & + & + & + & 0 & + & - \\
\hline 4 & patuh & + & + & 0 & + & + & 0 & 0 & - & + & + & + & + & + & - \\
\hline 5 & saleh & + & + & + & - & + & - & - & - & - & + & + & + & + & - \\
\hline 6 & setia & + & + & + & - & + & + & + & - & - & + & + & 0 & 0 & - \\
\hline 7 & sembah & + & 0 & - & - & + & - & + & - & - & + & 0 & 0 & 0 & + \\
\hline 8 & sopan & + & + & + & - & - & + & + & - & - & + & + & 0 & 0 & - \\
\hline 9 & taat & + & + & 0 & + & + & 0 & 0 & - & + & + & + & + & + & - \\
\hline 10 & takwa & + & - & - & - & + & - & - & - & - & + & + & + & + & - \\
\hline 11 & takluk & + & - & - & - & - & - & - & + & - & 0 & 0 & 0 & 0 & - \\
\hline 12 & tunduk & + & - & 0 & + & - & - & - & - & + & + & + & 0 & 0 & - \\
\hline
\end{tabular}

The meaning components contained in each lexeme can be studied based on three dimensions, namely ACTOR, RECIPIENT, and FORM, as follows.

\section{DOER Dimension}

Based on the DOER dimension, a set of lexemes which means taat 'obedient' in Indonesian can be described, as follows.

The bakti 'devotion' lexeme has a meaning component of + HUMAN 
The hormat 'respect' lexeme has a meaning component of +HUMAN.

The menurut 'obey' lexeme has a meaning component of +HUMAN.

The patuh 'subservient' lexeme has a meaning component of +HUMAN.

The saleh 'pious' lexeme has a meaning component of +HUMAN.

The setia 'loyal' lexeme has a meaning component of +INSANI.

The sembah 'worship' lexeme has a meaning component of +HUMAN.

The sopan 'polite' lexeme has a meaning component of +HUMAN.

The taat 'obedience' lexeme has a meaning component of +HUMAN.

The takwa 'piety' lexeme has a meaning component of +HUMAN.

The takluk 'surrender' lexeme has a meaning component of +HUMAN.

The tunduk 'submission' lexeme has a meaning component of +HUMAN.

\section{REPECIENT Dimension}

Based on the RECIPIENT dimension, a set of lexemes which means taat 'obedient' in Indonesian can be described, as follows.

The bakti 'devotional' lexeme has meaning components of + PARENTS, 0 PEOPLE, + GOD, $+\mathrm{KING}$

The hormat 'respect' lexeme has meaning components of + PARENTS, + PEOPLE, 0 A SPOUSE, + KING.

The menurut 'to obey' has meaning components of + PARENTS, + FELLOWMAN, + REGULATION, + GOD, 0 A SPOUSE, + KING, + COMMAND.

The patuh 'subservient' lexeme has meaning components of + PARENTS, 0 FELLOWMAN, + REGULATION, + GOD, 0 A SPOUSE, 0 KING, + COMMAND :

The saleh 'pious' lexeme has meaning components of + PARENTS, + FELLOWMAN, + GOD.

The setia 'loyal' lexeme has meaning components of + PARENTS, + FELLOWMAN, + GOD. + A SPOUSE, + KING.

The sembah 'worship' lexeme has meaning components of 0 PARENTS, + GOD, + KING.

The sopan 'polite' lexeme has meaning components of + PARENTS, + FELLOWMAN, + A SPOUSE, + KING.

The taat 'obedience' lexeme has meaning components of + PARENTS, 0 FELLOWMAN, + REGULATION, + GOD, + KING, 0 A SPOUSE, 0 KING, + COMMAND

The takwa 'piety' lexeme has meaning components of + GOD.

The takluk 'surrender' lexeme has meaning components of + ENEMY.

The tunduk 'submission' lexeme has meaning components of + REGULATION, + COMMAND, 0 FELLOWMAN.

\section{FORM Dimension}

Based on the WUJUD 'FORM' dimension, a set of Indonesian lexemes which means taat 'obedient' can be described, as follows.

The bakti 'devotion' lexeme has meaning components of + NORMATIVE, + APPRESIATIVE, 0 WORSHIP, 0 COMMITMENT.

The hormat 'respect' lexeme has meaning components of + NORMATIVE, + APPRECIATIVE, 0 WORSHIP, 0 COMMITMENT.

The menurut 'to obey' lexeme has meaning components of + NORMATIVE, + APPRECIATIVE, 0 WORSHIP, + COMMITMENT.

The patuh 'subservient' lexeme has meaning components of + NORMATIVE, + APPRESIATIVE, + WORSHIP, + COMMITMENT. 
The saleh pious lexeme has meaning components of + NORMATIVE, + APPRECIATIVE, + WORSHIP, + COMMITMENT.

The setia 'loyal' lexeme has meaning components of + NORMATIVE, + APPRECIATIVE, 0 WORSHIP, 0 COMMITMENT.

The sembah 'worship' lexeme has meaning components of 0 NORMATIVE, +0 APPRECIATIVE, 0 WORSHIP, 0 COMMITMENT, + CUP BOTH PALMS.

The sopan 'polite' lexeme has meaning components of + NORMATIVE, + APPRECIATIVE, 0 WORSHIP, 0 COMMITMENT.

The taat 'obedience' lexeme has meaning components of + NORMATIVE, + APPRECIATIVE, + WORSHIP, + COMMITMENT.

The takwa 'piety' lexeme has meaning components of + NORMATIVE, + APPRECIATIVE, + WORSHIP, + COMMITMENT.

The takluk 'surrender' lexeme has meaning components of 0 NORMATIVE, 0 APPRECIATIVE, 0 WORSHIP, 0 COMMITMENT.

The tunduk 'submission' lexeme has meaning components of + NORMATIVE, + APPRECIATIVE, 0 WORSHIP, 0 COMMITMENT.

From the meaning component description, a set of taat 'obey' lexemes can be classified into several groups, as follows.

\section{Group I}

There are three lexemes, namely taat obedient, menurut obeying, and patuh 'subservient'. If they are opposite, in the three lexemes there are components of common meaning. From the DOER dimension: + HUMAN PEOPLE, from the RECIPIENT dimension: + PARENTS, + REGULATIONS, + GOD, 0 A COUPLE, and + COMMAND. From the FORM dimension: + NORMATIVE, + APPRECIATIVE, + COMMITMENT. If contrasted, the three lexemes have a distinguishing component. The RECIPIENT dimensions of menurut 'to obey' lexeme are +PEOPLE, + KING, while the patuh 'subservient' lexeme are 0 PEOPLE, 0 KING. The FORM dimensions of the menurut 'obey' lexeme are 0 WORSHIP, while the patuh 'subservient' lexeme is + WORSHIP.

\section{Group II}

In group II there are saleh 'pious' and takwa 'piety' lexeme. If they are opposed, from the DOER dimension of the two lexemes there is a shared component +HUMAN. From the RECIPIENT dimension, the two lexemes have the shared component + GOD. From the FORM dimension, the two lexemes have a shared component + NORMATIVE, + APPRECIATIVE, + WORSHIP, + COMMITMENT. In contrast, both lexemes have a diagnostic component. From the RECIPIENT dimension, saleh pious + PARENTS, + FELLOWSHIP, while takwa piety PARENTS, -FELLOWSHIP.

\section{Group III}

In group III there are two lexemes, namely bakti devotion and setia loyal. From the DOER dimension, bakti 'devotion' and setia 'loyal' have + HUMAN shared meaning components; from the RECIPIENT dimension, the common components are + PARENTS, + GOD, and + KING. From the FORM dimension, the shared components are + NORMATIVE, + APPRECIATIVE, 0 WORSHIP, 0 COMMITMENT. If they are opposite, both lexemes have a diagnostic component. From the RECIPIENT dimension, bakti 'devotion' is 0 FELLOWSHIP and +FELLOWSHIP, while setia 'loyal' is + A SPOUSE and bakti 'devotion' is - A SPOUSE. Group IV

In group IV there are two lexemes, namely hormat 'respect' and sopan 'polite'. The shared meaning component of the two lexemes is shown in the DOER dimension, namely + HUMAN; from the RECIPIENT dimension: + PARENTS, + PEOPLE, + KING; from the FORM 
dimension, there are shared components: + NORMATIVE, + APPRECIATIVE, 0 WORSHIP, and 0 COMMITMENT. If they are contrasted, both lexemes have a diagnostic component. From the RECIPIENT dimension, hormat 'respect' is 0 A SPOUSE, meanwhile, sopan 'polite' is + A SPOUSE.

\section{Group V}

In group $\mathrm{V}$ there are two lexemes, namely takluk 'surrender' and tunduk 'submission'. If they are opposed, both lexemes have a shared meaning component. From the DOER dimension is + HUMAN; from the FORM dimension is 0 WORSHIP and 0 COMMITMENT. If they are contrasted, both lexemes have a diagnostic component. From the RECIPIENT dimension, tunduk 'submission' is 0 PEOPLE, + RULE, - ENEMY, + COMMAND, while takluk 'surrender' is -FELLOWMAN, - REGULATION, + ENEMY, - COMMAND. From the FORM dimension, takluk 'surrender' is 0 NORMATIVE, 0 APPRECIATIVE, while tunduk 'submission' is + NORMATIVE, and + APPRECIATIVE.

Based on the shared meaning components and the diagnostic meaning components, a set of lexemes which means taat 'obedient' can be formulated into the following tree diagram.

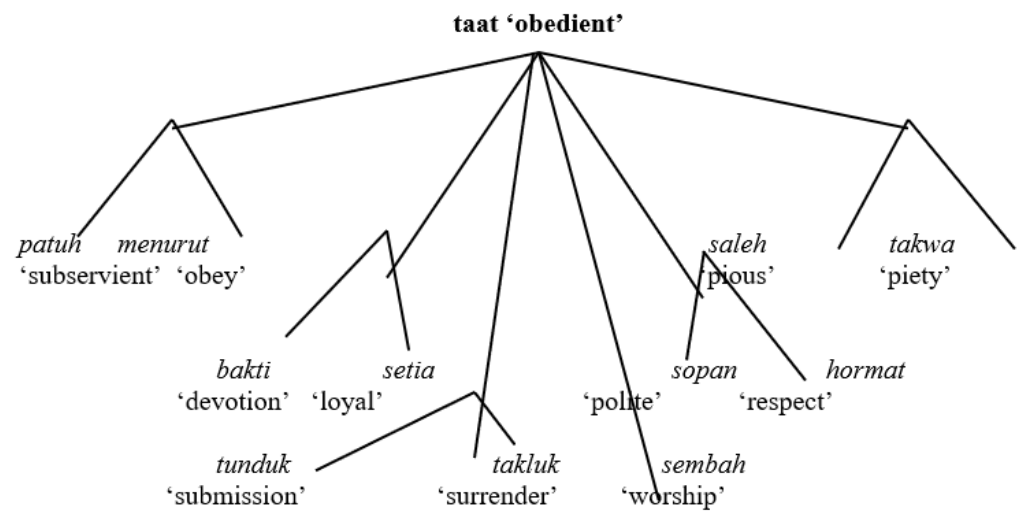

\section{Conclusion}

The data show that twelve lexemes mean taat 'obedient' in Indonesian. Based on the shared meaning component, taat 'obedient' lexeme has the status as superordinate or hyperonym. Through contrast and opposition procedures, this set of lexemes can be divided into five groups. In group I, the patuh 'subservient' lexeme cohyponymizes with menurut 'obey'. In group II, the saleh 'pious' lexeme is cohyponymous with takwa 'piety'. In group III, the bakti 'devotion' lexeme is cohyponymous with setia 'loyal'. In group IV, the hormat 'respect' lexeme is cohyponymous with sopan 'polite'.

In group V, the takluk 'surrender' lexeme cohyponymizes with tunduk 'submission'. The component meaning of the sembah 'worship' lexeme is different from the others, from the RECIPIENT dimension is + GOD, + KING; from the FORM dimension, ibadah 'worship' + NORMATIVE, 0 APPRECIATIVE, 0 WORSHIP, 0 COMMITMENT, and + CUP BOTH PALMS. Since the components of meaning tend to differ from each other, the hierarchical structure is unbranched. The other five groups form a branched hierarchical structure. 


\section{References}

[1] Asisda W.A.P., "Penggunaan Kata-kata Bermakna Penginaan, Fitnah, Ancaman, dan Pencemaran Nama Baik dalam Media Sosial Tinjauan Semantik Leksikal," Pros. Semin. Int., pp. 736-744, 2013.

[2] A. Maturbongs, "Peran Semantik Verba Bahasa Nafri (Semantic role of The Nafri Language Verbs)," Met. J. Penelit. Bhs., vol. 13, no. 2, pp. 125-140, 2015.

[3] Sutarsih, "Kata Bermakna Membesar Dalam Bahasa Jawa," Jala Bhs., vol. 13, no. 2, pp. 193-209, 2017.

[4] Sutarsih, “"Hiponimi Kata Mencuci Dalam Bahasa Indonesia,” Jala Bhs. J. Ilm. Kebahasaan, vol. 14, no. 1, pp. 91-114, 2018, doi: https://doi.org/10.36567/jalabahasa.v14i1.184.

[5] W. E. S. Nurlina, “Leksikon Bermakna "Aktivitas Telinga” Dalam Bahasa Jawa," Suar Betang J. Kebahasaan, Kesastraan, dan Pengajarannya, vol. VII, no. 2, p. 32, 2012.

[6] D. M.R., "Medan Makna Rasa Mata Dalam Bahasa Bugis Bone," Telaga Bhs. J. Ilm. Kebahasaan dan Kesastraan, vol. 2, no. 1, pp. 61-70, 2014.

[7] M. A. Khak, "Verba Indrawi Penglihatan: Analisis Makna," Met. J. Penelit. Bhs., vol. 11, no. 1, pp. 57-72, 2013.

[8] E. A. Nida, "Componental Analysis of Meaning," in Componental Analysis of Meaning an Introduction to Semantic Structures, Paris: Mouton, 1975, pp. 7,23,32,88-89,174.

[9] Wedhawati, "Konfigurasi Medan Leksikal (+suara+insan) dalam Bahasa Indonesia," Universitas Gadjah Mada, 1997.

[10] J. Lyons, Semantics, 1st ed. Australia: Cambridge University Press, 1977.

[11] Sudaryanto, "Metode dan Aneka Teknik Analisis Bahasa," in Metode dan Aneka Teknik Analisis Bahasa: Pengantar Penelitian Wahana Kebudayaan secara Linguistis, 1st ed., Yogyakarta: Yogyakarta: Sanata Dharma University Press, 2015, pp. 1-308.

[12] S. Nardiati, “"Makna Ungkapan Penghubung Sehubungan Dengan pada Surat Dinas,"” in Prosiding: Hasil Penelitian Kebahasaan dan Kesastraan, 2017, pp. 3-12.

[13] S. Nardiati, Komponen Makna "Mencuri" dan “Mencari," 1st ed. Yogyakarta: Amatera, 2018. 